\title{
Article \\ Sulfur-Induced Resistance against Pseudomonas syringae pv. actinidiae via Triggering Salicylic Acid Signaling Pathway in Kiwifruit
}

\author{
Zhuzhu Zhang ${ }^{1}$, Youhua Long ${ }^{1, *}$, Xianhui Yin ${ }^{1, *} \mathbb{D}$ and Sen Yang ${ }^{2}$ \\ College of Agriculture, Guizhou University, Guiyang 550025, China; gs.zzzhang20@gzu.edu.cn \\ 2 Kiwifruit Engineering \& Technology Research Center, Guizhou University, Guiyang 550025, China; \\ yangsen2008812@163.com \\ * Correspondence: gzlyh126@126.com (Y.L.); xhyin@gzu.edu.cn (X.Y.)
}

check for updates

Citation: Zhang, Z.; Long, Y.; Yin, X.; Yang, S. Sulfur-Induced Resistance against Pseudomonas syringae pv. actinidiae via Triggering Salicylic Acid Signaling Pathway in Kiwifruit. Int. J. Mol. Sci. 2021, 22, 12710. https:// doi.org/10.3390/ijms222312710

Academic Editor: Gabriella Szalai

Received: 21 October 2021

Accepted: 15 November 2021

Published: 24 November 2021

Publisher's Note: MDPI stays neutral with regard to jurisdictional claims in published maps and institutional affiliations.

Copyright: (c) 2021 by the authors. Licensee MDPI, Basel, Switzerland. This article is an open access article distributed under the terms and conditions of the Creative Commons Attribution (CC BY) license (https:// creativecommons.org/licenses/by/ $4.0 /)$.

\begin{abstract}
Sulfur has been previously reported to modulate plant growth and exhibit significant antimicrobial activities. However, the mechanism underlying its diverse effects on plant pathogens has not been elucidated completely. The present study conducted the two-year field experiment of sulfur application to control kiwifruit canker from 2017 to 2018. For the first time, our study uncovered activation of plant disease resistance by salicylic acid after sulfur application in kiwifruit. The results indicated that when the sulfur concentration was $1.5-2.0 \mathrm{~kg} \mathrm{~m}^{-3}$, the induced effect of kiwifruit canker reached more than $70 \%$. Meanwhile, a salicylic acid high lever was accompanied by the decline of jasmonic acid. Further analysis revealed the high expression of the defense gene, especially $A c P R-1$, which is a marker of the salicylic acid signaling pathway. Additionally, AcICS1, another critical gene of salicylic acid synthesis, was also highly expressed. All contributed to the synthesis of increasing salicylic acid content in kiwifruit leaves. Moreover, the first key lignin biosynthetic $A c P A L$ gene was marked up-regulated. Thereafter, accumulation of lignin content in the kiwifruit stem and the higher deposition of lignin were visible in histochemical analysis. Moreover, the activity of the endochitinase activity of kiwifruit leaves increased significantly. We suggest that the sulfur-induced resistance against Pseudomonas syringae pv. actinidiae via salicylic activates systemic acquired resistance to enhance plant immune response in kiwifruit.
\end{abstract}

Keywords: sulfur; induced resistance; canker of kiwifruit; salicylic acid; lignin; resistance mechanisms

\section{Introduction}

The bacterial canker of kiwifruit is a devastating disease caused by Pseudomonas syringae pv. actinidiae (Psa). Since its initial discovery in Japan in 1984 [1], now this disease has been found in many countries, such as Italy [2], France [3], and New Zealand [4]. This disease was first discovered in the Hunan province, China, where it destroyed about $133.3 \mathrm{hm}^{2}$ of kiwifruit orchards [5]. As the menace of the disease increased year after year, many kiwi-growing regions were infected with the disease, resulting in severe loss of yield worldwide.

Chemical control remains the primary option in the canker of kiwifruit during agricultural production. However, extensive chemical pesticides to control plant diseases can often generate resistance and cause pesticide-contaminated environments. Therefore, a novel and environmentally friendly method were explored in this study to control the canker of kiwifruit, and the underlying mechanism was elucidated. Sulfur is one of the 16 essential elements involved in plant growth and development, which can actively participate in the maintenance of the physiological function of the living organisms, regulate plant metabolism [6-8], and may also improve both the yield and the quality of kiwifruit $[9,10]$. Sulfur-induced resistance (SIR) denotes the reinforcement of natural resistance in the plants against pathogens by triggering different metabolic processes [11-15]. It can be directly or 
indirectly involved in plant disease resistance in various ways by participating in physiological and biochemical processes such as expression of plant cytoplasmic membrane structure, modulation of the protein metabolism, and regulation of enzyme activity [16-19].

Salicylic acid and jasmonic acid are essential signal molecules in the process of pathogen infection $[20,21]$, which are involved in various aspects of regulating plant growth, environmental stress, and defense response to pathogens [22,23]. There is a close relationship between JA- and SA-mediated signal transduction pathway, synergy, and antagonism [24,25]. Exogenous chlorogenic acid, by activating the salicylic acid signaling pathway in peach, improved the fruit quality parameters of peach. Additionally, it enhanced the activities of pathogenesis-related proteins such as chitinase and glucanase [26]; $\beta$-1,3-glucanase and chitinase are essential pathogenesis-related proteins, and they can substantially destroy the cell wall of the pathogenic fungi and hydrolyze bacterial peptidoglycan, which plays an important role in pathogen defense [13,27-29]. When external factors stimulate plants, they can be induced and accumulated in a significant concentration. After chitosan was applied to tobacco, the expression of defense genes in tobacco was activated by SA, thereby inducing resistance to tobacco mosaic virus [30]. These SA-mediated responses also involve an increase in phenolic compounds such as lignin [31], which is a vital component of the secondary cell as it can enhance the structural strength of the host cell walls and form the basis of a self-defense strategy against the plant pathogen [32]. It was reported that lignin deposition could limit the pathogens to infected sites and prevent systemic infection [33].

In our previous study, we have reported that sulfur not only significantly promoted the growth, development, and fruit quality of kiwifruit but also induced the disease resistance of kiwifruits to Psa. The control effects in the greenhouse and field were observed to be more than $70 \%[9,10,34]$. However, the mechanism of how sulfur can significantly improve disease resistance is still puzzling. In this study, the purpose was to evaluate the induce effect of sulfur on kiwifruit canker in the field and provide insight into the mechanisms involved. The results showed for the first time that the activation of the SA signaling pathway might play an essential role in the mechanism of sulfur-induced kiwifruit resistance to canker, mainly highly expressed AcPR-1 and AcPAL genes. Thus, SAR is activated, resulting in increased lignin content and high disease-related proteins activity. This work is significant because sulfur is inexpensive and can be obtained easily. Understanding sulfur-induced resistance to kiwifruit canker and its possible physiological and molecular mechanisms will provide a new sustainable control strategy for kiwifruit canker, thus contributing to the development of new disease control approaches.

\section{Results}

\subsection{Soil Treatment of Sulfur Enhances Kiwifruit against Pseudomonas syringae pv. actinidiae}

Sulfur has a significant induced effect on kiwifruit canker (Figure 1). In all sulfur concentrations, kiwifruit canker disease severity decreased significantly. The greatest decrease in the disease severity was observed for sulfur concentration of $1.5-2.0 \mathrm{~kg} \mathrm{~m}^{-3}$. 
(a)

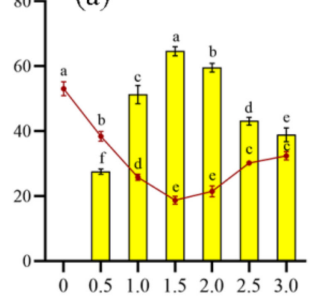

Sulfur concentration $\left(\mathrm{kg} \mathrm{m}^{-3}\right)$

2017

(c)

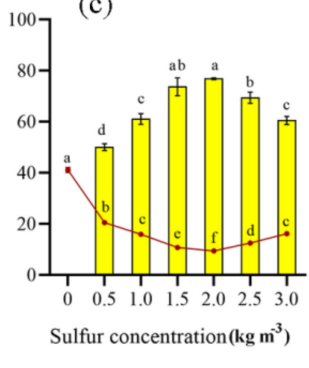

2018 (b)

- Disease severity $(\%)$

$\square \quad$ Induced effect (\%)

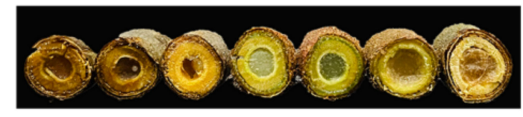

(d)

$\rightarrow$ Disease severity (\%)

$\square$ Induced effect (\%)

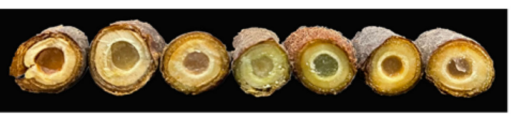

Figure 1. Induction effect on kiwifruit canker of sulfur. (a) Disease severity of kiwifruit canker disease and induce effect of sulfur in 2017; (b) Phenotypic map of kiwifruit stem canker disease after different sulfur treatments in 2017; (c) Disease severity of kiwifruit canker disease and induce effect of sulfur in 2018; (d) Phenotypic map of kiwifruit stem canker disease after different sulfur treatments in 2018. Note: Different lowercase letters indicate significant differences between different sulfur treatments at $p<0.05$.

The first year (2017) and the second year (2018) were $63.70-64.40 \%$ and $74.16-74.91 \%$ lower than the control, respectively. The $1.5-2.0 \mathrm{~kg} \mathrm{~m}^{-3}$ sulfur concentration treatment had the best induction effect on kiwifruit canker, with $59.54-64.65 \%$ in the first year and $73.74-76.90 \%$ in the second year, which was significantly different from other treatments. It shows that sulfur application can reduce the disease severity of kiwifruit canker, inhibit the occurrence of the disease and improve its induction effect to control the occurrence of kiwifruit canker effectively. Compared with 2017, the induction effect of sulfur application on kiwifruit canker increased by $12.33 \%$ and $22.54 \%$ in 2018 . The incidence of kiwifruit canker in 2017 corresponds to the phenotype shown in Figure 1a, while 2018 corresponds to the phenotype shown in Figure 1b.

\subsection{Sulfur Improved Photosynthetic Characteristics of Kiwifruit}

It can be seen from Figure 2 that after sulfur application (2017 and 2018), the net photosynthetic rate, transpiration rate, and stomatal conductance of kiwifruit were significantly increased, and the change of intercellular $\mathrm{CO}_{2}$ concentration was opposite, showing a gradual downward trend (Figure 2). When the sulfur concentration was $2.0 \mathrm{~kg} \mathrm{~m}^{-3}$, $\mathrm{Pn}, \mathrm{Tr}$, and Gs reached the maximum. In 2017, compared with no sulfur application, it increased by $59.73 \%, 74.07 \%$, and $50.00 \%$, respectively. In 2018 , it still maintained significant enhancements of $69.05 \%, 60.94 \%$, and $62.50 \%(p<0.05)$. It indicated that when the fertilization concentration was $2.0 \mathrm{~kg} \mathrm{~m}^{-3}$, the net photosynthetic rate and transpiration rate were increased by regulating stomatal conductance to promote $\mathrm{CO}_{2}$ exchange. 


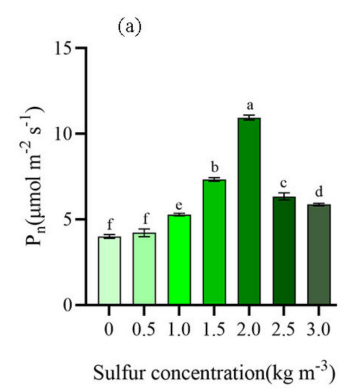

(c)

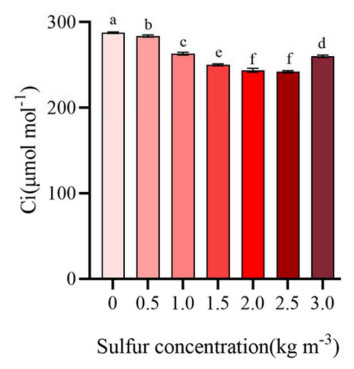

(b)

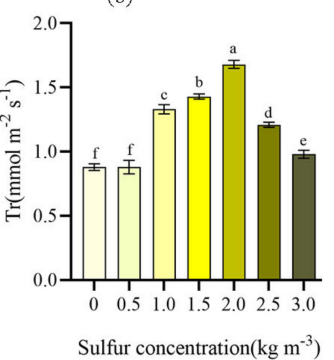

(d)

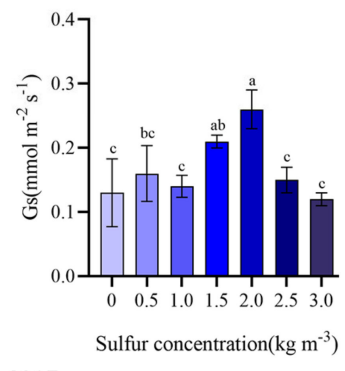

(e)

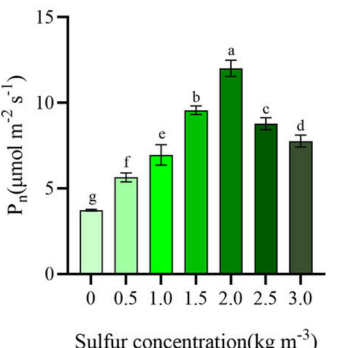

(g)

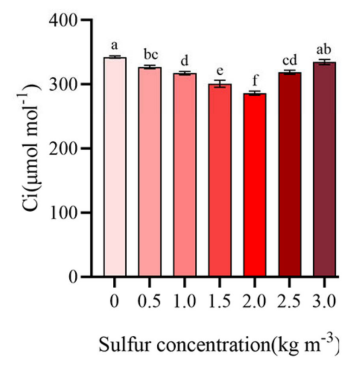

(f)

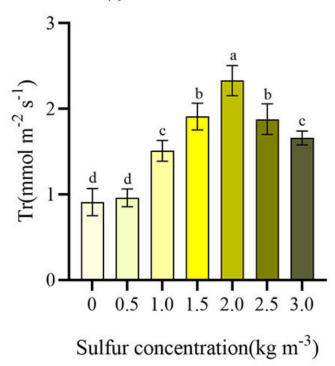

(h)

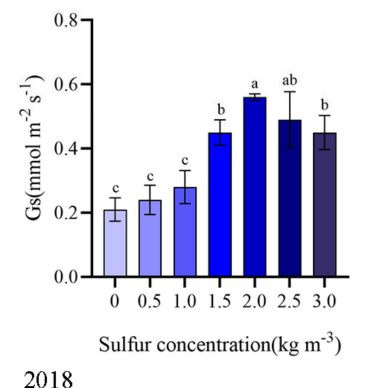

Figure 2. Effects of sulfur on photosynthetic characteristics of kiwifruit leaves. Different letters indicate significant difference between means at $p<0.05$. Value are means $\pm \mathrm{SE}(\mathrm{n}=3)$. Abbreviations: Pn, net photosynthesis rate; $\mathrm{Tr}$, transpiration rate; $\mathrm{Gs}$, stomatal conductance; and $\mathrm{C}_{\mathrm{i}}$, intercellular $\mathrm{CO}_{2}$ concentration. (a) Net photosynthesis of kiwifruit leaves in 2017; (b) Transpiration rate of kiwifruit leaves in 2017; (c) Intercellular $\mathrm{CO}_{2}$ concentration of kiwifruit leaves in 2017; (d) Stomatal conductance of kiwifruit leaves in 2017; (e) Net photosynthesis of kiwifruit leaves in 2018; (f) Net photosynthesis of kiwifruit leaves in 2018; (g) Intercellular $\mathrm{CO}_{2}$ concentration of kiwifruit leaves in 2018; (h) Stomatal conductance of kiwifruit leaves in 2018.

\subsection{Effect of Sulfur on Chlorophyll Content in Kiwifruit Leaves}

Chlorophyll a and chlorophyll b did not change significantly in the first year of sulfur application (2017) but increased first and then decreased with the increase of sulfur concentration in the second year of sulfur application (2018). Moreover, the sulfur concentration was higher in the range of $1.5-2.0 \mathrm{~kg} \mathrm{~m}^{-3}$, increased by $60.28-62.42 \%$ and $55.56-62.26 \%$ compared with no sulfur (Figure 3).

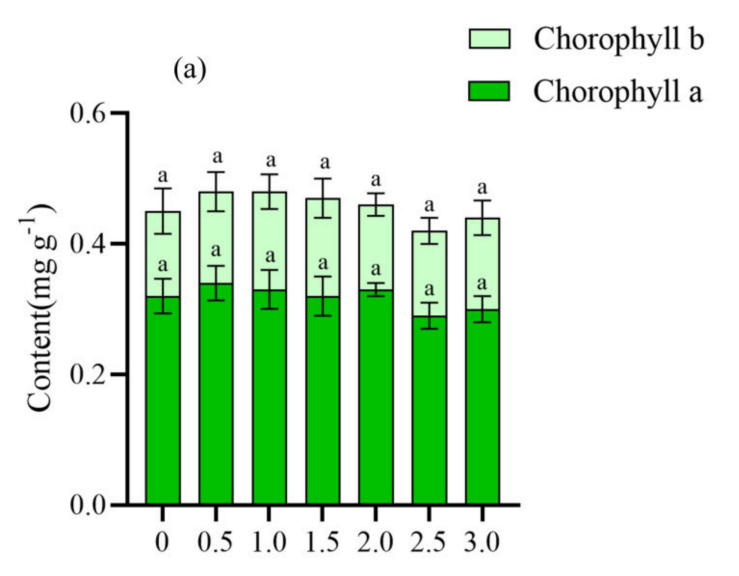

Sulfur concentration $\left(\mathrm{kg} \mathrm{m}^{-3}\right)$

2017

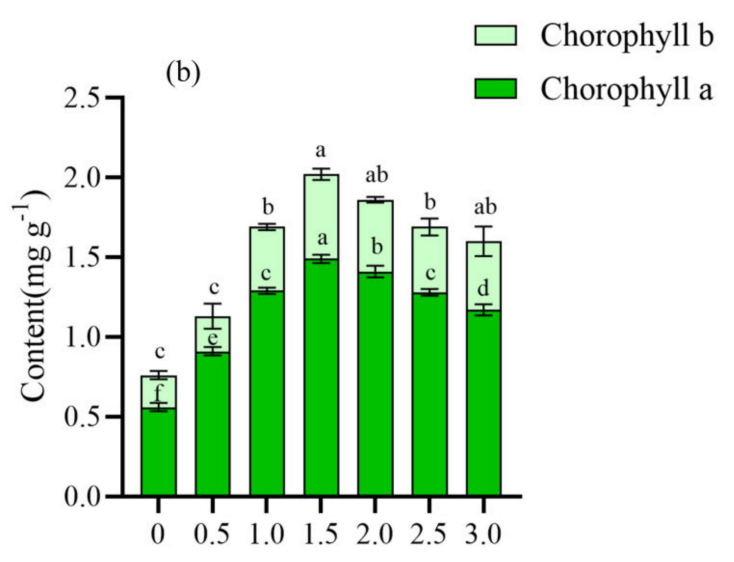

Sulfur concentration $\left(\mathrm{kg} \mathrm{m}^{-3}\right)$

2018

Figure 3. Effect of sulfur on chlorophyll content in kiwifruit leaves. Different letters indicate significant difference between means at $p<0.05$. Value are means $\pm \mathrm{SE}(\mathrm{n}=3)$. (a) Chlorophyll content of kiwifruit leaves in 2017; (b) Chlorophyll content of kiwifruit leaves in 2018. 


\subsection{Sulfur Activates the SA Signaling Pathways and Inhibits the JA Signaling Pathway}

To clarify the changes in salicylic acid and jasmonic acid contents in kiwifruit after sulfur application and their relationship, we measured the contents of salicylic acid and jasmonic acid in kiwifruit leaves in 2017 and 2018 years of sulfur application (Figure 4). The response of salicylic acid to sulfur application was stronger than jasmonic acid, and the content of salicylic acid was higher than jasmonic acid for two consecutive years. When the sulfur concentration was $1.5 \mathrm{~kg} \mathrm{~m}^{-3}$, the content was high. In 2017 and 2018, salicylic acid content increased by 1.09 and 1.94 times, respectively, compared with no sulfur application. Surprisingly, there was a negative correlation between the change in SA content and JA content.

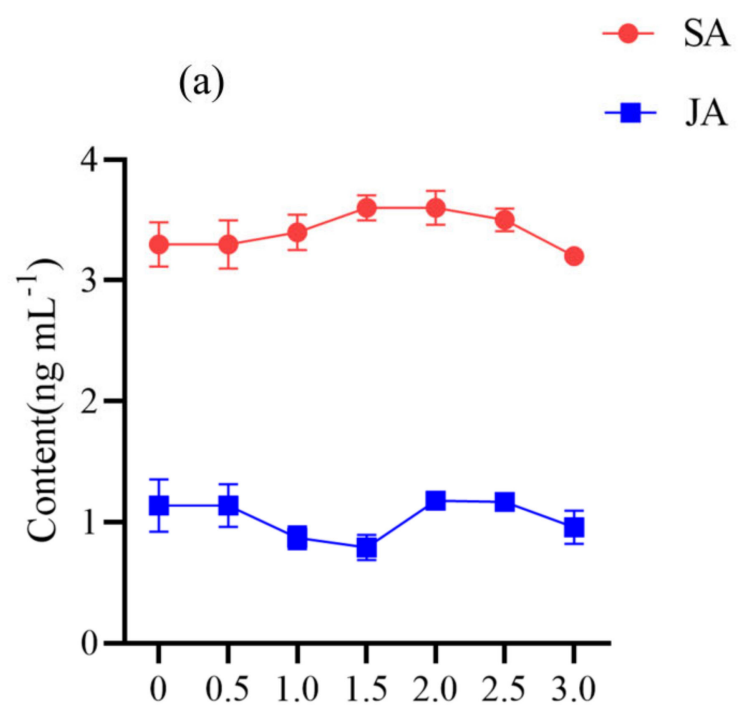

Sulfur concentration $\left(\mathrm{mg} \mathrm{m}^{-3}\right)$

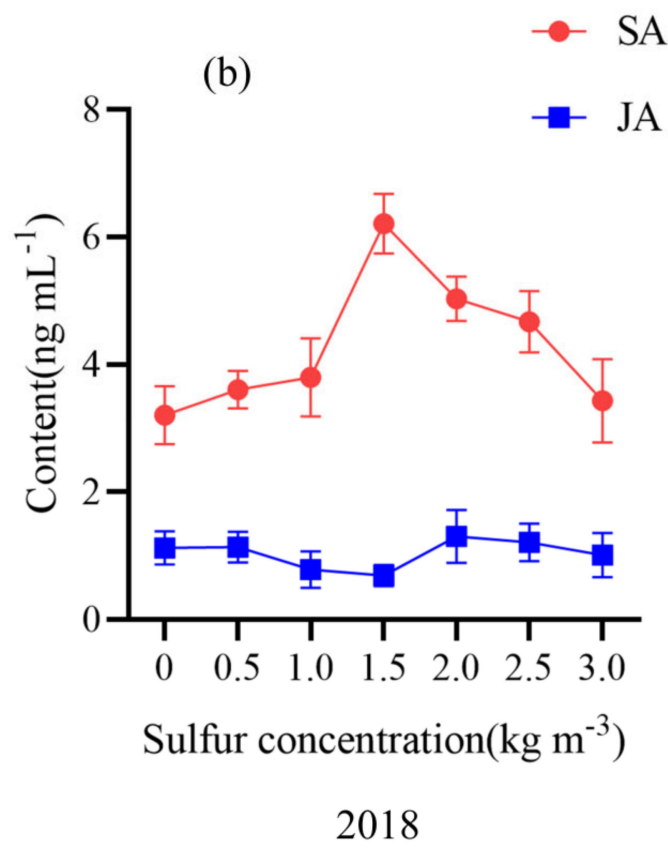

Figure 4. Effect of sulfur on salicylic acid and jasmonic acid content. Abbreviations: SA, salicylic acid; JA, jasmonic acid. Value are means \pm SE $(n=3)$. (a) Contents of salicylic acid and jasmonic acid in kiwifruit leaves in 2017; (b) Contents of salicylic acid and jasmonic acid in kiwifruit leaves in 2018.

\subsection{Expression of Resistance-Genes in Leaf and Stem of Kiwifruit under Sulfur Treatment}

In order to understand the ability of sulfur to activate the resistance gene of kiwifruit after two years of sulfur application, the expression of the resistance gene in kiwifruit leaves and stems was analyzed by gene expression circle diagram (Figure 5). In 2017, AcICS1 gene and $A c P R-1$ gene showed continuous high expression at sulfur concentration of $1.5-2.0 \mathrm{~kg}$ $\mathrm{m}^{-3}$ compared with no sulfur application. It increased by $26.67-36.54 \%$ and $42.86-49.21 \%$, respectively (Figure 5a). AcPAL and AcPR-8 were highly expressed in kiwifruit stem under this sulfur concentration range, and the gene expression levels were increased by $5.49-5.82$ times and 5.35-5.77 times compared with those without sulfur application (Figure 5b). In 2018, AcICS1, AcPR-1, AcPR-5, and AcPR-10 showed high expression levels at the sulfur application concentrations of $1.5-2.0 \mathrm{~kg} \mathrm{~m}^{-3}$, which were 1.07-1.13, 1.57-1.62, 1.55-1.59, and 4.91-5.00 times higher than without sulfur application, respectively (Figure 5c). AcPAL, $A c P R-1, A c P R-5$, and $A c P R-10$ were highly expressed in kiwifruit stem, which was 3.85$4.54,2.37-2.42,1.79$, and 7.86-11.19 times higher than those without sulfur application, respectively (Figure $5 d$ ). 

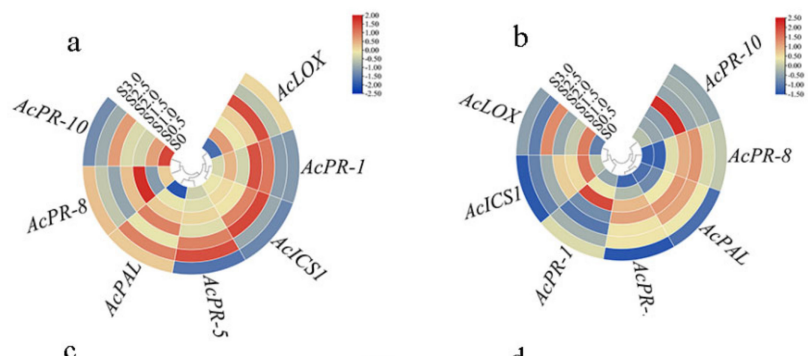

2017
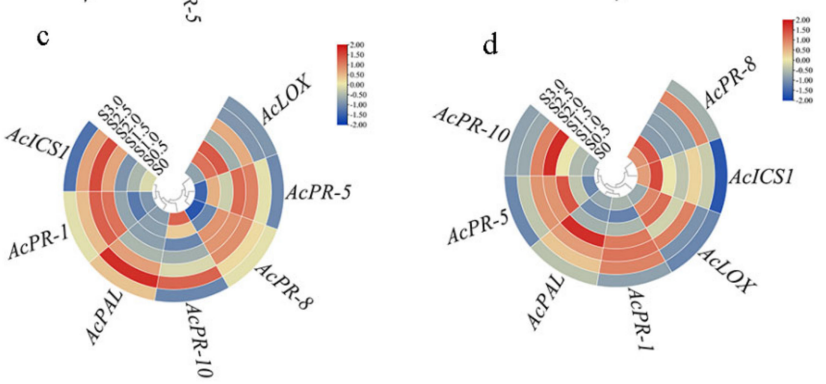

2018

Figure 5. Expression pattern of defense-genes in leaves and stems of kiwifruit treated with sulfur. (a) Gene expression of kiwifruit leaves in 2017; (b) Gene expression of kiwifruit stem in 2017; (c) Gene expression in kiwifruit leaves in 2018; (d) Gene expression of kiwifruit stem in 2018. Note: The red and blue circles show up- and downregulated genes. The size of the circle was drawn to show the counts of differentially expressed genes.

\subsection{Induction of Higher Lignin Accumulation and Deposition}

The results of the distribution and deposition of lignin in the kiwifruit stem have been shown in Figure 6, respectively. It was observed that lignin was mainly distributed in the two layers of kiwifruit stem; one layer was distributed between the epidermis and xylem of the kiwifruit stem (the outer layer), whereas the other layer was found between the xylem and pith of the kiwifruit stem (the inner layer). With increasing sulfur supply on kiwifruit, the lignin content in kiwifruit stem first increased rapidly and then declined (Figure 6), whereas the color change trend was light red-deep red-light red.

a

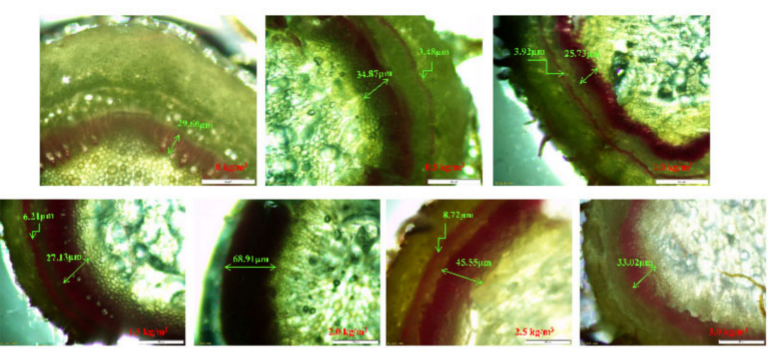

b

2017
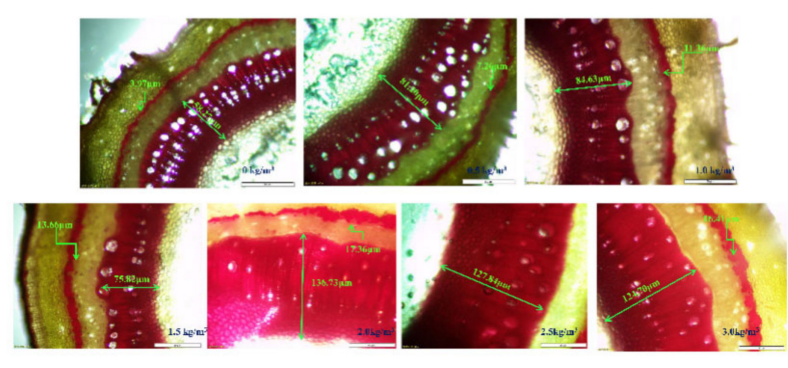

2018

Figure 6. Effects of different sulfur concentrations on the lignin distribution and deposition in the stems of kiwifruit. (a) Lignin deposition in kiwifruit stem in 2017; (b) Lignin deposition in kiwifruit stem in 2018. 
In 2017, when the sulfur concentration was $1.5-2.0 \mathrm{~kg} \mathrm{~m}^{-3}$, the length of lignin staining bands in the inner layer was $27.35-68.91 \mu \mathrm{m}\left(2.0\right.$ and $3.0 \mathrm{~kg} \mathrm{~m}^{-3}$ covered the outer layer due to the wide inner layer). There were significant effects upon $2.0 \mathrm{~kg} \mathrm{~m}^{-3}$ sulfur treatment, which resulted in a dark-red coloration. However, without sulfur treatment, the outer color was light, and almost no lignin was observed to be dyed red (Figure 6a). In 2018 (Figure $6 \mathrm{~b}$ ), the relationship between sulfur concentration and lignin content in stems was consistent with 2017. The application of sulfur at $1.5 \mathrm{~kg} \mathrm{~m}^{-3}$ was found to be 2.51 times higher than that without sulfur application $(p<0.05)$. The change in lignin deposition is consistent with the lignin content (Figure 7). Overall, the lignin distribution and deposition in 2018 were significantly better than in 2017 after sulfur application. The suitable sulfur concentration $\left(1.5-2.0 \mathrm{~kg} \mathrm{~m}^{-3}\right)$ can promote lignin accumulation in the kiwifruit stem. It may thus play an essential role as a potential physical barrier in sulfur-induced resistance of kiwifruit to canker.

(a)

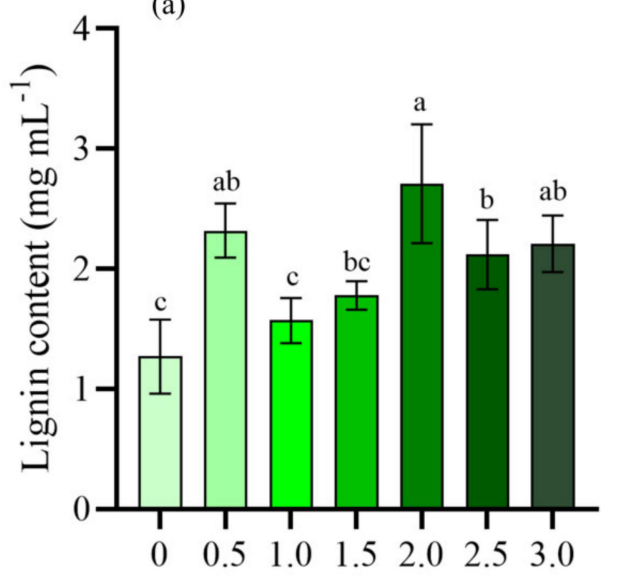

Sulfur concentration $\left(\mathrm{kg} \mathrm{m}^{-3}\right)$

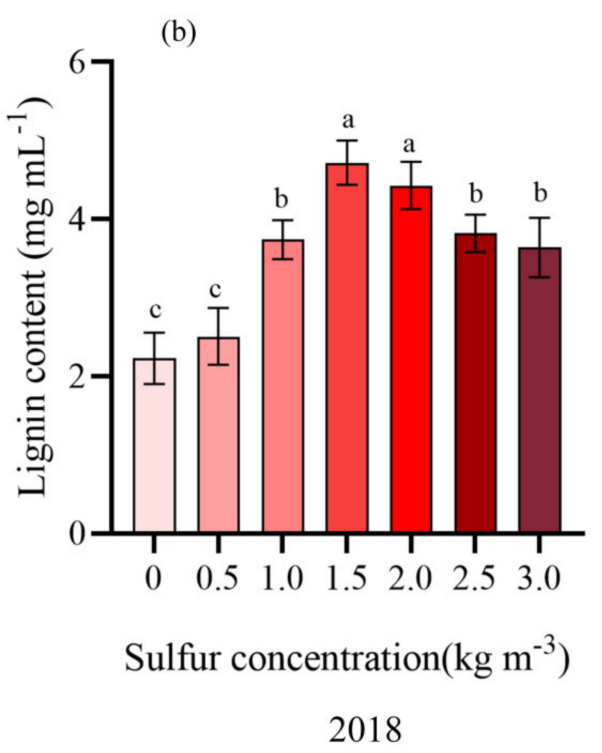

Figure 7. Effects of different sulfur concentration on lignin content in the stems of kiwifruit. Different letters indicate significant difference between means at $p<0.05$. Value are means $\pm \mathrm{SE}(\mathrm{n}=3)$. (a) Lignin content in kiwifruit stem in 2017; (b) Lignin content in kiwifruit stem in 2018.

\subsection{Chitinase and $\beta-1,3-$ Glucanase Activity}

Sulfur concentration in $1.5-2.0 \mathrm{~kg} \mathrm{~m}^{-3}$ can improve kiwifruit disease-related protease activity. In 2017, there was mainly an increase in the endochitinase activity, which was 75.93-76.36\% higher than that without sulfur application (Figure 8a). In this range, there was no significant effect on chitinase and $\beta$-1,3-glucanaseenzymatic activity. In 2018, the activities of endochitinase showed the highest peak at $2.0 \mathrm{~kg} \mathrm{~m}^{-3}$ treatment compared with no sulfur treatment and increased by $85.54 \%$ (Figure 9), reaching a difference significant level $(p<0.05)$. However, when sulfur concentration was higher than $2.0 \mathrm{~kg} \mathrm{~m}^{-3}$, the enzyme activity demonstrated a marked declining trend. Moreover, sulfur also exhibited a significant benefit in favor of $\beta$-1,3-glucanase activity (Figure $8 \mathrm{c}, \mathrm{f}$ ). It was found that in response to increasing sulfur concentration, the activity first increases and then decreases gradually. Additionally, the application of $1.5 \mathrm{~kg} \mathrm{~m}^{-3}$ promoted $\beta$-1,3-glucanaseenzymatic activity quite efficiently and, as compared to no sulfur treatment, increased by $59.80 \%$, with the difference being significant. 
a

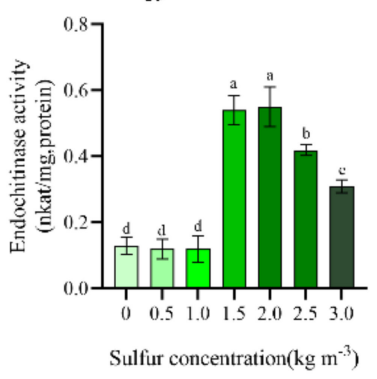

d

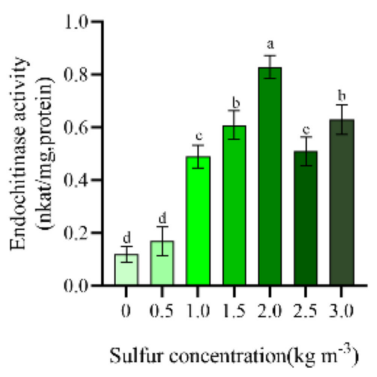

b

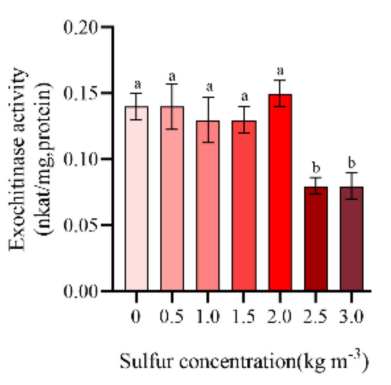

2017

e

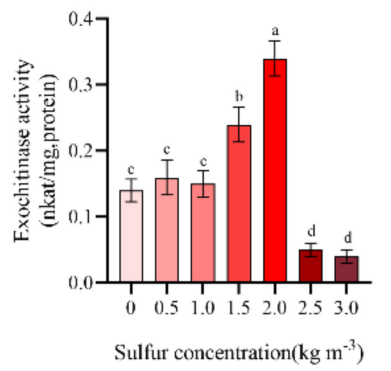

$\mathrm{c}$

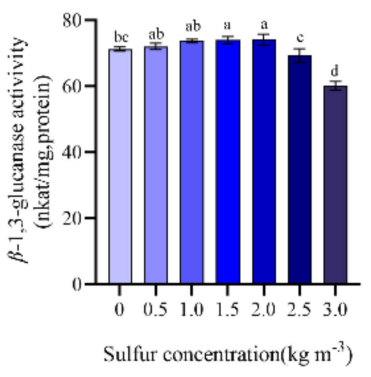

f

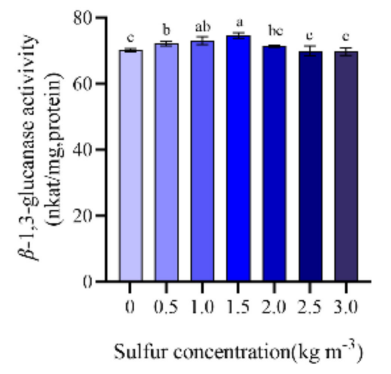

2018

Figure 8. Effect of different sulfur treatments on chitinase and $\beta-1,3-$ glucanase activities in the leaves of kiwifruit. Different letters indicate significant difference between means at $p<0.05$. (a) Endochitinase activity in kiwifruit leaves in 2017; (b) Exochitinase activity in kiwifruit leaves in 2017; (c) $\beta$-1,3-glucanase activity in kiwifruit leaves in 2017; (d) Endochitinase activity in kiwifruit leaves in 2018; (e) Exochitinase activity in kiwifruit leaves in 2018; (f) $\beta$-1,3-glucanase activity in kiwifruit leaves in 2018.

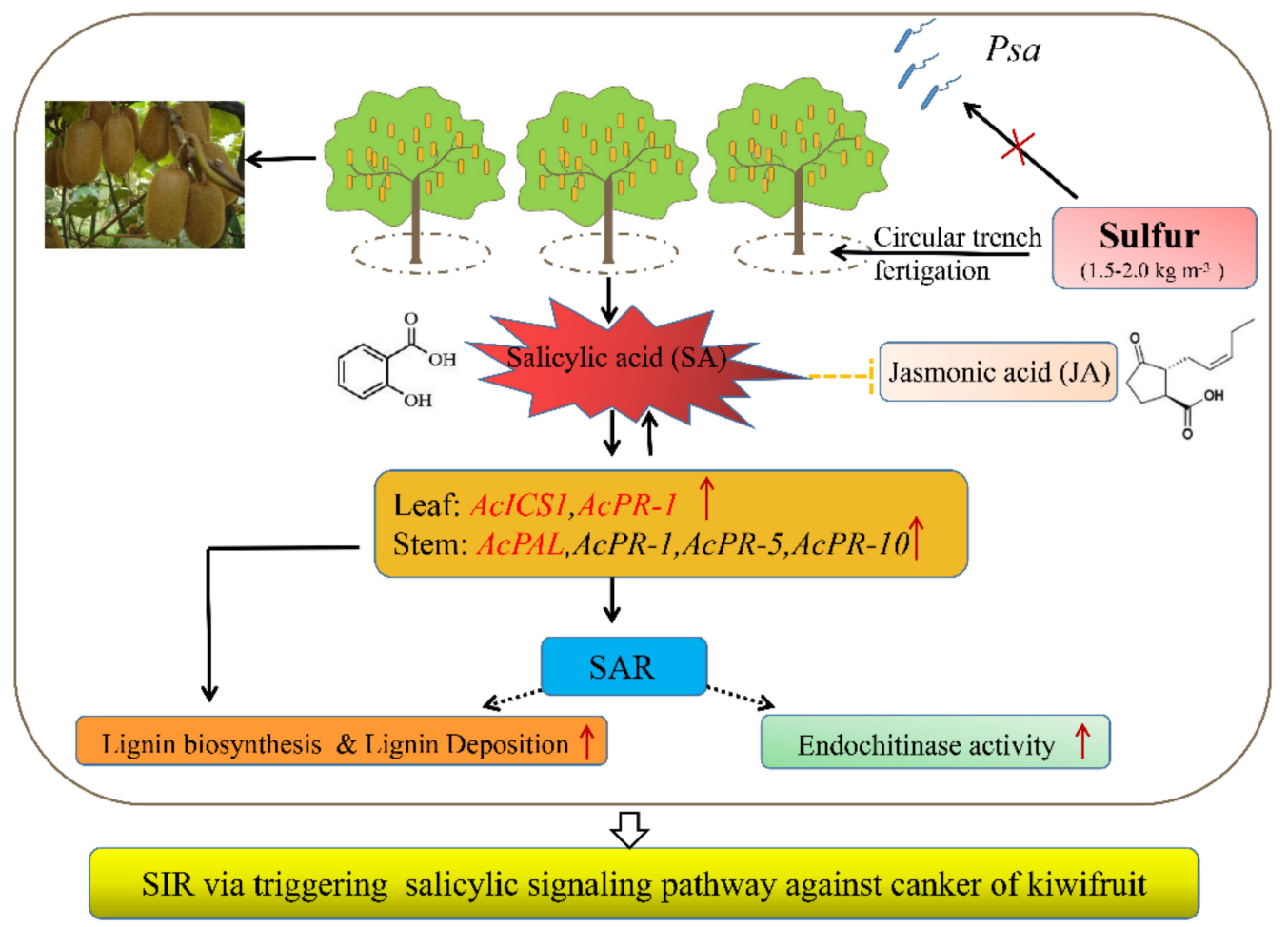

Figure 9. A proposed model describing how sulfur mediates salicylic acid and its pathway to regulate kiwifruit canker resistance was proposed. $P R-1$ and ICS1 genes are involved in the activation of signals on SA and then activates systemic acquired resistance (SAR), contributing to the resistance of kiwifruit to Pseudomonas syringae pv. actinidiae. 


\section{Discussion}

Bacterial canker of kiwifruit caused by Pseudomonas syringae pv. actinidiae (Psa) has become the primary problem in the development of kiwifruit industry worldwide $[35,36]$. The disease often shows symptoms such as branch canker, leaf necrosis, and flower rot and has serious harm. It has expanded and spread in kiwifruit planting areas and lacks effective control measures. In particular, the characteristic kiwifruit series developed in many regions of China (such as the variety 'Guichang' in this study) are also highly susceptible, resulting in widespread destruction of orchards, serious economic losses, and serious setbacks to the enthusiasm of fruit farmers. Therefore, how to use various measures to effectively control kiwifruit bacterial canker has become the key to the development of the kiwifruit industry. At present, in the case that other prevention and control technologies have reached the bottleneck, the use of host plant disease resistance has become an important breakthrough in the prevention and control of canker disease, especially for kiwifruit with excellent traits that are also highly susceptible. Plant-induced disease resistance is an important research field of plant protection. It has become an effective supplement to chemical pesticides for controlling plant diseases due to its small dosage and good environmental compatibility [37], which is in line with the goal of reducing pesticide use and controlling pests and increasing production in China. Especially for some special diseases, there is no good chemical control method, through mineral nutrition regulation is a new method worth exploring [38].

Mineral nutrition not only promotes the healthy growth of plants but can also participate in plant disease resistance through diverse mechanisms [39-42]. Sulfur, as the fourth element needed by plants after nitrogen, phosphorus, and potassium, requires a large amount of nutrients [43], which can induce resistance to various plant diseases (SIR). At present, several mechanisms underlying SIR production in plants have been reported. These include (1) accumulation of cysteine, glutathione, sulfur-rich proteins, and the release of volatile $\mathrm{S}$ compounds, but cysteine and GSH play key roles in the process of disease resistance [44-47]; (2) regulation of the disease resistance signaling (salicylic, jasmonic acid, ethylene, abscisic acid, etc.) or the defense responses (ROS, stomatal opening, and closing), but these can vary significantly in the different disease systems [48-50]; and (3) production of the various plant antitoxins (such as glucosinolates and camalexin) $[11,50]$. Moreover, in the bacterial diseases caused by P. syringae, although no other sulfur control diseases and corresponding SIR reports have been documented previously, GSH could significantly induce salicylic signaling pathway independent of NPR1 and thereby increase the resistance of Arabidopsis to P. syringae [51]. Additionally, cysteine (rather than GSH) played a key role in the regulation of effector-triggered immunity of $P$. syringae [44].

In the early stage, it was observed that kiwifruit in the field was often in a state of sulfur deficiency. It was found that the application of an appropriate dose of sulfur could significantly reduce the incidence of kiwifruit canker (control effect $>70 \%$ ). In addition, a continuous tracking following sulfur application was performed for two years, and the same control effect was found. However, sulfur had no direct bactericidal effect on Psa [34], thus indicating that SIR played an important role in kiwifruit canker resistance. However, its mechanism is still not fully unraveled.

At present, the studies on sulfur and plant resistance at home and abroad are primarily focused on fungal diseases. However, the possible effects on bacterial infections have not been extensively evaluated. In this study, the results showed that when the sulfur concentration was $1.5-2.0 \mathrm{~kg} \mathrm{~m}^{-3}$, the disease severity of kiwifruit canker decreased, and the induced effect was improved. In addition, sulfur also significantly improved physical and chemical parameters of kiwifruit fruit quality, which was consistent with Yin et al. [9]. Furthermore, the application of sulfur improved the net photosynthesis, transpiration rate, and stomatal conductance of kiwifruit leaves, which was consistent with the study [52]. This may be due to the amount of sulfur application once greater than $2.0 \mathrm{~kg} \mathrm{~m}^{-3}$, wherein the acidity of the soil is reduced, not suitable for the growth of kiwifruit plants, and kiwifruit plant growth potential is weak, resulting in kiwifruit plant resistance to canker. 
The initial manifestation of plant infection with pathogens is rapid and localized death of infected cells, known as hypersensitive response (HR); the infected plants produce new resistance, which can be extended to the whole plant and usually become systemic acquired resistance (SAR). The significant sign of SAR is through salicylic acid signal transmission. Studies have shown that salicylic acid is mainly synthesized in plants through phenylalanine lyase (PAL) and isochorismate synthase (ICS)-mediated phenylalanine pathway. In this study, from 2017 to 2018, AcICS1 in kiwifruit leaves and stems showed continuous high expression. However, there was no significant change in AcPAL gene expression (Figure 5). In addition, after two years (2017 and 2018) of sulfur application, the content of jasmonic acid in kiwifruit leaves fluctuated little, and the difference between the treatments was not significant, indicating that sulfur having little effect on the improvement of JA content in kiwifruit leaves was consistent with Lv et al. (2021), which indicated that after sulfur treatment, SA signal in kiwifruit was activated, while JA signal might be inhibited. Interestingly, high expression of salicylic acid synthesis marker gene $A c P R-1$ was high expression. Therefore, we speculated that the high expression of the AcICS1 gene might be mainly responsible for SA synthesis in stems and leaves of sulfur-treated kiwifruit. Our results are consistent with Jiao et al. [26]. PRs are divided into 17 families, such as pathogenesis-related gene $1(P R-1)$ and exotic fruit-like protein (PR-5), which are often used to explain SA-mediated plant defense responses [53,54]. $P R-8$ gene family encodes lysozyme and chitosanase, which kill Gram-positive bacteria. PR-10 participates in plant defense responses through SA signal transduction pathway [55]. This study showed that when the sulfur concentration was $1.5-2.0 \mathrm{~kg} \mathrm{~m}^{-3}$, the gene expression levels of $A c P R-5$, $A c P R-8$, and $A c P R-10$ in kiwifruit stems in 2018 were all activated (Figure 5d). A multitude of previous studies has shown that the production and deposition of lignin is one of the important mechanisms for inducing disease resistance [56,57]. When pathogens infect the plants, they often cause rapid lignification of the infected parts, which implies that lignin analogs are produced and can accumulate in the different parts such as the cell wall, intercellular layer, and the cytoplasm, which can prevent or delay the growth of pathogens and form a physical obstacle for the pathogen infection. Lignin biosynthesis can also play an important role in the long-distance transport of water, a process critical to plant survival [58]. The PAL gene is the key gene in lignin and phenolic compounds synthesis [59], and it is closely related to the expression of system acquired resistance [60]. In this study, when the sulfur concentration was $1.5-2.0 \mathrm{~kg} \mathrm{~m}^{-3}$, the AcPAL expression in stems was significantly increased in 2017 and 2018 (Figure 5), which was consistent with the increasing trend of lignin content (Figure 7). Therefore, the results of this experiment may be due to the significant increase in the AcPAL gene in the kiwifruit stem after sulfur application, which is involved in lignin synthesis and significantly increases the cell wall strength, thus hindering the invasion of Psa and disease. This is similar to the results obtained in the previous studies related to the control of pear fruit diseases by calcium [61], the improvement of rice sheath blight resistance by silicon [62], and the significant reduction in the incidence of soybean wilt, Fusarium, and Aspergillus by manganese [63]. Moreover, another mechanism by highlighted bacteria could spread in the plants was through the reproduction and secretion of bacterial fluid in the xylem, thereby blocking the ducts of plants to cause the disease $[57,64]$. A large number of studies have shown that the induction of plant resistance to pathogens may be attributed to the activation of highly coordinated defense-related enzymes such as CHI and GLU. Chitinase and $\beta$-1,3-glucanase are two important disease-related proteins. According to the different positions that chitinase can act on a potential substrate, it has been divided into endo- and exochitinases [44]. According to the different amino acid sequences, plant chitinases can be divided into four different categories. Among them, class III and class V chitinases can display additional lysozyme activity, which can effectively hydrolyze the alkaline enzyme of peptidase. They can potentially catalyze the hydrolysis of the $\beta-1,4$ glycosidic bond between peptidase N-acetylglucosamine and N-acetylcytic acid in the bacterial cell wall, destroy the peptidase scaffold, and expand as well as split the cells under the action of internal osmotic pressure, thereby resulting in the bacterial cracking [44]. In addition, in cotton, the expression of specific chitinase member genes was noted to be significantly correlated with the formation of secondary walls [65]. In this study, it was found that $1.5-2.0 \mathrm{~kg} \mathrm{~m}^{-3}$ sulfur 
treatment significantly increased the activities of chitinase exoenzymes and endoenzymes, and endoenzymes can contribute substantially to the chitinase activity (Figure 8a,d). An identical, fast increase trend in that range was observed. It can be speculated that sulfur may hydrolyze peptidoglycans in the pathogenic bacteria of kiwifruit canker, thereby disrupting the bacterial completion, in agreement with Gupta et al. [66].

Numerous studies have suggested that under the stress of exogenous substances, salicylic acid promotes the synthesis of lignin to improve the resistance to external pathogenic microorganisms [59,67]; it also increases disease-related protein activity, including chitinase and glucanase [61] and active resistance gene expression [26,30]. In this study, it was found that under sulfur treatment, activities of chitinase and $\beta$-1,3-glucanase were induced to accumulate in kiwifruit leaves, mainly in the sulfur concentration of $1.5-2.0 \mathrm{~kg} \mathrm{~m}^{-3}$ range. In addition, it was also observed that the lignin content of the kiwifruit stem increased, and lignin deposition was obvious under this sulfur concentration range. However, whether the enhanced effect of sulfur on kiwifruit resistance to canker is due to the formation of a physical barrier, or if it can regulate the various metabolic processes between the plant and the pathogen, which can thereby induce the expression of disease resistance in the plants and the possible consequences of the synergistic effect of these two different aspects, need further analysis.

\section{Materials and Methods}

\subsection{Materials}

The sulfur fertilizer ( $\geq 95 \%$ purity) was purchased from Zhengan Agricultural Sci $\&$ Tech Co. Ltd., Shijiazhuang, China. The organic fertilizer (total nutrient content $\geq 4 \%$, organic matter content $\geq 30 \%$ ) was purchased from Guizhou Jilong Ecological Tec Co. Ltd., Guiyang, China.

\subsection{Field Experiments}

The field experiments were conducted for consecutive years (2017-2018) in a commercial orchard located in Xiuwen county, Guizhou province, China $\left(26^{\circ} 45^{\prime} 34.4^{\prime \prime} \mathrm{N}, 106^{\circ} 65^{\prime} 82.36^{\prime \prime} \mathrm{E}, 1168\right.$ $\mathrm{m}$ a.s.l) on 8 April. Field trials commenced on 24 December 2016; five kiwifruit plants were for one repetition and four repetitions were there for each sulfur concentration. The vines of the cultivar 'Guichang' were 18 years old, with 74 plants planted per $667 \mathrm{~m}^{2}$, including 68 female plants, trained in a T-bar trellis system. The trees received pollution-free planting cultivation techniques, and there were signs of infected Pseudomonas syringae pv. actinidiae, with the kiwifruit canker incidence reaching 76.7\% in 2015 and 66.7\% in 2016 [34].

The soil type in the experimental orchard is yellow soil, slightly alkaline (pH7.16). The soil samples were collected from a depth of $0-60 \mathrm{~cm}$ and analyzed [68]. Their concentrations are as follows: containing a total nitrogen content of $178 \mathrm{mg} \mathrm{kg}^{-1}$, available phosphorus content of $4.80 \mathrm{mg} \mathrm{kg}^{-1}$, available potassium content of $106.72 \mathrm{mg} \mathrm{kg}^{-1}$, available sulfur content of $4.80 \mathrm{mg} \mathrm{kg}^{-1}$. The sulfur powder and organic fertilizer were mixed homogeneously. The concentration of sulfur fertilizer has been listed in Table 1. We performed circular ditching (i.e., dig a rill outside the edge of the crown, 30-50 cm in width and $40 \mathrm{~cm}$ in depth; we used sulfur powder and organic fertilizer to make the base fertilizer mixed with topsoil to fill the ditch). Each experiment was performed in four different replicates.

Table 1. The concentration of sulfur treatment used in this study.

\begin{tabular}{cr}
\hline Number & Treatment \\
\hline $\mathrm{S}_{0}$ & Sulfur-deficiency $+10 \mathrm{~kg} \mathrm{~m}^{-3}$ organic fertilizer (as a control) \\
$\mathrm{S}_{1.0}$ & $1.0 \mathrm{~kg} \mathrm{~m}^{-3}$ Sulfur powder $+10 \mathrm{~kg}$ organic fertilizer \\
$\mathrm{S}_{1.5}$ & $1.5 \mathrm{~kg} \mathrm{~m}^{-3}$ Sulfur powder $+10 \mathrm{~kg}$ organic fertilizer \\
$\mathrm{S}_{2.0}$ & $2.0 \mathrm{~kg} \mathrm{~m}^{-3}$ Sulfur powder $+10 \mathrm{~kg}$ organic fertilizer \\
$\mathrm{S}_{2.5}$ & $2.5 \mathrm{~kg} \mathrm{~m}^{-3}$ Sulfur powder $+10 \mathrm{~kg}$ organic fertilizer \\
$\mathrm{S}_{3.0}$ & $3.0 \mathrm{~kg} \mathrm{~m}^{-3}$ Sulfur powder $+10 \mathrm{~kg}$ organic fertilizer \\
\hline
\end{tabular}




\subsection{Assessment of Disease Incidence: Disease Severity Index and Induction Effect}

The incidence of kiwifruit bacterial canker disease was determined according to Long et al. [34]. The disease severity index was measured according to the rating scale of 1-6 after the incidence of canker in kiwifruit during the bleeding period (April) was investigated following sulfur application in the field for two years (2017-2018).

In the index, $1=$ no disease (HR), $2=$ less than $1 / 3$ disease symptoms $(\mathrm{R}), 3=2 / 3$ disease symptoms (MR), $4=1 / 2-3 / 4$ disease symptoms (MS), $5=$ more than $3 / 4$ disease symptoms (S), and $6=$ whole plants completely necrotic. Disease severity was calculated based on the formula $=\Sigma$ (Number of plants infected with pathogenic bacteria $\times$ Representative value of corresponding class)/(Total number of investigated plants $\times$ Representative value of the highest-class $) \times 100$. Induction effect $(\%)=($ Disease severity of the control-Disease severity of the treatment)/Disease severity of the control $\times 100$.

\subsection{Photosynthesis Parameters and Fluorescence Parameters}

The weather conditions met the requirements of clear sky and no wind, and we recorded the net photosynthesis rate (Pn), transpiration rate (Tr), stomatal conductance (Gs), and intercellular $\mathrm{CO}_{2}$ concentration (Ci) by LI-COR 6400 portable photosynthesis system (Li-COR, Huntington Beach, CA, USA).

\subsection{Leaf Chlorophyll Content}

The time to perform the analyses was 8 April 2017 and 2018, at 8:30 a.m. to 10:30 a.m., with randomly selected kiwifruit leaves with the same growth after different sulfur treatments. Kiwifruit leaves chlorophylls were isolated from acetone extraction technology. The fresh kiwifruit leaves $(0.5 \mathrm{~g})$ were cut into $1 \mathrm{~cm}$ slices and placed in $10 \mathrm{~mL}$ extract solution. The slices were soaked in the complete dark for about $20 \mathrm{~h}$ until the leaves became white. Two hundred $\mu \mathrm{L}$ pigment solution samples were taken, and the extraction solution was used as the control. The absorption value was determined by Tecan Infinite M200 of Switzerland, and the chlorophyll content was calculated according to previously described formulas [69].

\subsection{Salicylic Acid (SA) and Jasmonic Acid (JA) Contents Measurements}

Quantification of JA and SA in kiwifruit leaves was performed using a liquid chromatographyelectrospray ionization tandem mass spectrometry (ESI) method according to De et al. [70] with slight modification. Chromatography conditions were modified by using a C18 column (Thermo, $250 \times 4.6 \mathrm{~mm}$ ), the temperature of the column oven was $28^{\circ} \mathrm{C}$, and the injection volume was $3.0 \mu \mathrm{L}$ and set at a flow rate of $0.4 \mathrm{~mL} \mathrm{~min}^{-1}$. The mobile phases were $0.1 \%$ formic acid (mobile phase A) and $0.1 \%$ formic acid-acetonitrile solution (mobile phase B). Elution program ( $\mathrm{t}$ min $[\% \mathrm{~A}: \% \mathrm{~B}]$ ) was: $0 \mathrm{~min}$ (95:5), $1.0 \mathrm{~min}$ (30:70), $2 \mathrm{~min}$ (30:70), $2.01 \mathrm{~min}$ (95:5), and $3 \mathrm{~min}$ (95:5). Mass spectrometry conditions were modified using a high-performance liquid chromatography-electrospray tandem mass spectrometry (LC-ESI-MS/MS) system. The ESI source operation parameters were as follows: the desolvation temperature was set at $650{ }^{\circ} \mathrm{C}$ with desolvation gas flow of $1000 \mathrm{~L} \mathrm{~h}^{-}$and the cone gas at a flow rate of $30 \mathrm{~L} \mathrm{~h}^{-1}$. Data acquisition was accomplished with MassLynx V4.1 software (Waters Corporation) to deal with the base-peak ion current patterns of positive and negative ion modes. Meanwhile, the multiple reaction monitoring (MRM) mode was used for quantification.

\subsection{RNA Extraction and Quantitative RT-PCR}

Leaves and stems were collected at 8:30 a.m. to 10:30 a.m. randomly with the same growth after different sulfur treatments. The stems and leaves of kiwifruit were collected as RNA extraction materials in kiwifruit canker orchards. All RNA extraction materials were snap-frozen in liquid nitrogen and stored at $-80{ }^{\circ} \mathrm{C}$ for standby use. A total of $0.5 \mathrm{~g}$ leaf and $0.5 \mathrm{~g}$ stem were ground in liquid nitrogen, respectively. Total RNA was extracted using the Plant Total RNA Isolation Kit (Huayueyang Biotechnology Co., LTD, Beijing, China) and synthesized into cDNA using RevertAid First-strand cDNA Synthesis Kit (Thermo Scientific, Waltham, MA, USA), the expression levels of AcPR-1, AcPR-5, 
AcPR-8, AcPR-10, AcPAL, AcICS1, and AcLOX were determined using AcActin as the reference gene for normalization. The gene-specific primers are provided in Table 2. Primers for quantitative real-time PCR (RT-qPCR) were designed by design net station (https: / / www.idtdna.com/Scitools / Applications/RealTimePCR/ access on 20 October 2021) on 15 May 2017 and 2018, respectively.

Table 2. Sequences for primers used in real-time fluorescent quantitative PCR.

\begin{tabular}{ccc}
\hline $\begin{array}{c}\text { Gene } \\
\text { Name }\end{array}$ & Forward Primer & Reverse Primer \\
\hline AcActin & CACCCTGTGCTGCTTACAGA & GAGAGAGAACGGCCTGAATG \\
$A c P R-1$ & GCCCCCGGTAAGGTTTGT & CGAACCAAGACCCACTATTGC \\
$A c P R-5$ & TTCACCAACCTCAGTTCT & ATCGTAAGCGTAACTATAAGC \\
$A c P R-8$ & TTTGGATGGAATTGACTTTGACA & TTCTTGCCACGACTGCTATA \\
$A c P R-10$ & TGCTACACTTTAATTGAAGGC & TTGCTTGTCATCTTAGTAATCG \\
$A c P A L$ & CGGAGCAACACAACCAAGA & CCTGACATAGTGCGACTACATAG \\
$A c I C S 1$ & AGGCGAGGCTTCTAATTG & ACAGCAAACTCACTCTCTC \\
$A c L O X$ & GGAGAAGCCATTGCCAAT & GGACGGTAATAAGTTGTGAAGTA \\
\hline
\end{tabular}

\subsection{Measurement of Lignin Content and Histochemical Analysis}

The measurement of lignin content was carried out based on the method from [71]. The stem was ground using liquid nitrogen, $0.1 \mathrm{~g}$ portion of the samples were weighed and collected in centrifuge tubes, then chlorophyll was extracted using 95\% ethanol and centrifuged at $5000 \times g$ for $10 \mathrm{~min}$, and the supernatant was removed. The deposition was washed three times with 2: $1(v / v)$ n-hexane: ethanol solution and centrifuged (5000× $\mathrm{g}, 10 \mathrm{~min}, 4^{\circ} \mathrm{C}$ ). The dried residue was then dissolved in $2.5 \mathrm{~mL}$ of acetyl bromide and glacial acetic acid $(1: 3, v / v)$ solution, heated in a water bath at $70{ }^{\circ} \mathrm{C}$, and incubated for $30 \mathrm{~min}$ followed by quick cooling in an ice-water bath. The reaction was terminated after the addition of $0.9 \mathrm{~mL} 2 \mathrm{~mol} \mathrm{~L}^{-1} \mathrm{NaOH}, 0.1 \mathrm{~mL} 7.5 \mathrm{~mol} \mathrm{~L}^{-1}$ hydroxylamine hydrochloride $4 \mathrm{~mL}$ glacial acetic acid, then mixed as well as centrifuged $\left(5000 \times \mathrm{g}, 5 \mathrm{~min}, 4^{\circ} \mathrm{C}\right)$, and $0.1 \mathrm{~mL}$ of the supernatant was collected, which was diluted with $3.9 \mathrm{~mL}$ glacial acetic acid. The optical density (OD) value was measured using the UV-1800 ultraviolet spectrophotometer (Varioskan Flash Multimode Reader, Thermo Fisher Scientific, Waltham, MA, USA) at 280 $\mathrm{nm}$. The results were expressed as $\mathrm{g} \mathrm{kg}^{-1}$ based on the fresh weight. All the measurements were performed in triplicates. After two years of sulfur application in the kiwifruit field in 2017-2018, the new and old stems of kiwifruits were immediately brought back to the laboratory to visualize the potential distribution and deposition of lignin. The histochemical test of the kiwifruit stem was conducted as described previously by [72] with minor modifications. The ring slices of the kiwifruit stem were observed under a stereomicroscope (Nikon, Tokyo, Japan). Then, each stem was cut into two semi-thin and ultrathin sections with an LKB-2188 microtome hand-cut cross-sections, the sample was placed on the slide, and a drop of pure ethanol was added. Thereafter, incubation for 5 min was performed for phloroglucinol (Wiesner) staining, then the fresh sections were left for 1-3 min before being mounted with $50 \% \mathrm{HCl}$, and finally, lactophenol was added to obtain the slides. The observations were conducted under natural light, and the photographs of the stained slices were examined and photographed under a transmission electron microscope (JEM-1230, Japan). The glass slides with lactophenol served as control. The presence of lignin was confirmed by the appearance of the red stain on the tissues. The shades of red color represent the amount of lignin content.

\subsection{Extraction and Assay of $\beta-1,3-$ Glucanase and Chitinase 4.9.1. Assay for Chitinase Activity}

Extraction of enzyme solution: $0.5 \mathrm{~g}$ of kiwifruit leaves was taken after two years of sulfur application, liquid nitrogen was added and then ground to the powder form, followed by the addition of $7 \mathrm{~mL}$ sodium acetate buffer $(\mathrm{pH}=5.0)$ homogenate. The mixture 
was centrifuged at $4{ }^{\circ} \mathrm{C}, 15,000 \times \mathrm{g}$ for $15 \mathrm{~min}$, after which the activity of extracellular chitinase and intracellular chitinase was analyzed by using the supernatant collected. The enzyme activity was measured based on a slightly modified method [73].

Standard curve of production: The different concentrations of N-acetyl glucosamine (Sigma Company, Burlington, MA, USA) at a volume of $1.5 \mathrm{~mL}$ were taken, and $2 \mathrm{~mL}$ of potassium ferricyanide solution was added, following which the mixture was boiled at $100{ }^{\circ} \mathrm{C}$ in a water bath for $15 \mathrm{~min}$. The measured optical density in the distilled water was considered as a control. In contrast, the optical density decreased with increasing $\mathrm{N}$-acetylamino glucose concentrations displaying a positive correlation, with n-acetyl glucosamine zero optical density being about 0.85 . The standard curve was thereafter plotted with the difference of optical density ( 0.85 minus the density of sugar) as the coordinate and $\mathrm{N}$-acetylglucosamine concentration as the abscissa.

Determination of endochitinase activity: The initial reaction solution used was the same as the assay of exochitinase. After being incubated at $37^{\circ} \mathrm{C}$ for $2 \mathrm{~h}$ and centrifuged at $1000 \times g$ for $2 \mathrm{~min}, 1.5 \mathrm{~mL}$ supernatant was collected and added with $0.1 \mathrm{~mL} 3 \%(w / v)$ desalted snail enzyme and $0.15 \mathrm{~mL} 1 \mathrm{~mol} \mathrm{~L}^{-1}$ sodium phosphate buffer $(\mathrm{pH}=7.1)$. The reaction solution was then placed in a constant temperature water bath at $37^{\circ} \mathrm{C}$ for one hour to hydrolyze the various chitin fragments produced by chitin endonucleases. A reaction solution containing a substrate and an enzyme (heat-inactivated) was used as a control. The amount of $\mathrm{N}$-acetylglucosamine produced was calculated by the method described above. One unit of $1 \mathrm{~g} \mathrm{~N}$-acetylglucosamine per hour was produced from the decomposition of colloidal chitin.

Determination of exochitinase activity: $1.5 \mathrm{~mL}$ of colloidal chitin solution (containing $6 \mathrm{mg}$ chitin) was absorbed, and $0.5 \mathrm{~mL} 50 \mathrm{mmol} \mathrm{L}^{-1}$ sodium acetate buffer solution ( $\mathrm{pH}$ $=4.5$ ) was added. The enzyme solution $0.4 \mathrm{~mL}$ and $0.1 \mathrm{~mL}$ of $75 \mathrm{~mol} \mathrm{~L}^{-1}$ sodium azide solution was mixed well. After being kept at $37^{\circ} \mathrm{C}$ for $2-4 \mathrm{~h}, 0.5 \mathrm{~mL}$ sodium borate buffer solution with a concentration of $0.8 \mathrm{~mol} \mathrm{~L}^{-1}(\mathrm{pH}=9.1)$ was added, and centrifugation at $1000 \times g$ for $5 \mathrm{~min}$ was performed. Thereafter, $1.5 \mathrm{~mL}$ supernatant was taken to measure the $\mathrm{N}$-acetylglucosamine produced by the chitin extracellular enzyme. As the standard control, $1.5 \mathrm{~mL}$ of the same treated solution, including substrate and enzyme (heat-inactivated), was used. The optical density was measured at $585 \mathrm{~nm}$, and the amount of N-acetylglucosamine produced was calculated from the standard curve based on the difference in the optical density (the standard control optical density minus the sample liquid optical density).

\subsubsection{Assay for $\beta-1,3-$ Glucanase Activity}

The enzyme activity was determined based on the method of [74]. Isochitinase was extracted from a crude enzyme solution. A total of $0.4 \mathrm{~mL}$ of $1 \mathrm{mg} \mathrm{mL}^{-1}$ laminarin (Sigma company), soluble in $\mathrm{pH}=5.0,50$ tendency $\mathrm{L}^{-1}$ sodium acetate buffer, was taken and added to $0.1 \mathrm{~mL}$ enzyme liquid (diluted up to 10 times). Thereafter, the mixture was incubated for $15 \mathrm{~min}$ at $37^{\circ} \mathrm{C}$, and then immediately, $0.5 \mathrm{~mL}$ copper reagent was added, mixed, and incubated in a $100{ }^{\circ} \mathrm{C}$ water bath for $10 \mathrm{~min}$. The mixture was thereafter cooled in ice water, and then $0.5 \mathrm{~mL}$ arsenic molybdate reagent was added. When the color turned to blue and distilled water was added after $3.5 \mathrm{~mL}$, the colorimetric determination of absorbance was carried out at $540 \mathrm{~nm}$ with the use of glucose in the standard curve and enzyme as well as the substrate alone as a control. One Katal (Kat) is defined as the enzyme activity that can catalyze to produce 1 mole of glucose, and the unit of enzyme activity is nkat $\mathrm{mg}^{-1}$ protein.

\section{Statistical Analysis}

All the data shown are average values of at least three replicates with standard deviations. A one-way analysis of variance followed by Tukey's HSD was performed. The data were analyzed using SPSS 18.0 (SPSS Inc., Chicago, IL, USA). 


\title{
6. Conclusions
}

In summary, this study demonstrates that $1.5-2.0 \mathrm{~kg} \mathrm{~m}^{-3}$ sulfur concentration mixed with $10 \mathrm{~kg} \mathrm{~m}^{-3}$ organic fertilizer when applied to the soil to control the canker of kiwifruit displayed remarkable effects. The control efficiency of sulfur on bacterial canker disease was as high as over 70\%, respectively. Furthermore, from the induced effects, photosynthetic traits, pathogenesis-related proteins (especially the endochitinase), and lignin content and expression of disease-resistant genes results, it is inferred that sulfur induces $P_{S a}$ resistance via the SA-dependent and JA-independent manner, implying that sulfur may be acting upstream of the SA and inhibits JA signaling pathways involved in plant defense, as described in Figure 9.

Author Contributions: Z.Z., Y.L., and X.Y designed the experiments; Z.Z., X.Y., and S.Y. performed the experiment; $Z . Z$ and S.Y. finished tables and figures; $Z . Z$ and Y.L. wrote the paper. All authors have read and agreed to the published version of the manuscript.

Funding: This work was supported by the Guizhou Science and Technology Plan Project: Development and application of intelligent system for kiwifruit pest identification and green prevention and control (2021237). Guizhou Science and Technology Program: Detection and Diagnosis of Kiwifruit Root Carcinoma and Green Air Defense Technology Research (20192401).

Institutional Review Board Statement: Not applicable.

Informed Consent Statement: Informed consent was obtained from all subjects involved in the study.

Data Availability Statement: All original articles used to support the findings of this study are available from the corresponding author upon request.

Acknowledgments: We would like to thank the Yang Qian Yuan Agricultural Technology Co., Ltd., Guizhou, China, for providing the necessary support for this study, such as kiwifruit plant materials and corresponding scientific research proving ground, etc.

Conflicts of Interest: The authors declare that they have no conflict of interest.

\author{
Abbreviations \\ Psa Pseudomonas syringae pv. actinidiae: \\ SA Salicylic Acid \\ JA Jasmonic Acid \\ SIR Sulfur-induced resistance \\ SAR Activates systemic acquired resistance
}

\section{References}

1. Scortichini, M.; Marcelletti, S.; Ferrante, P.; Petriccione, M.; Firrao, G. Pseudomonas syringae pv. actinidiae: A re-emerging, multi-faceted, pandemic pathogen. Mol. Plant. Pathol. 2012, 13, 631-640. [CrossRef] [PubMed]

2. Prencipe, S.; Gullino, M.L.; Spadaro, D. Pseudomonas syringae pv. actinidiae isolated from Actinidia chinensis Var. deliciosa in Northern Italy: Genetic diversity and virulence. Eur. J. Plant Pathol. 2018, 150, 191-204. [CrossRef]

3. Cunty, A.; Cesbron, S.; Poliakoff, F.; Jacques, M.A.; Manceau, C. Origin of the Outbreak in France of Pseudomonas syringae pv. actinidiae Biovar 3, the Causal Agent of Bacterial Canker of Kiwifruit, Revealed by a Multilocus Variable-Number Tandem-Repeat Analysis. Appl. Environ. Microbiol. 2015, 81, 6773-6789. [CrossRef] [PubMed]

4. Poulter, R.T.M.; Ho, J.; Handley, T.; Taiaroa, G.; Butler, M.I. Comparison between complete genomes of an isolate of Pseudomonas syringae pv. actinidiae from Japan and a New Zealand isolate of the pandemic lineage. Sci. Rep. 2018, 8, 10915. [CrossRef]

5. Yan, Z.F.; Xiao, X.Z.; Dao, Y.W. Preliminary study on kiwifruit diseases in Hunan. Sichuan Fruit Tree Sci. Technol. 1996, 18, $19-28$.

6. Jez, J.M. Structural biology of plant sulfur metabolism: From sulfate to glutathione. J. Exp. Bot. 2019, 70, 4089-4103. [CrossRef]

7. Kopriva, S.; Talukdar, D.; Takahashi, H.; Hell, R.; Sirko, A.; D'Souza, S.F.; Talukdar, T. Editorial: Frontiers of Sulfur Metabolism in Plant Growth, Development, and Stress Response. Front. Plant Sci. 2016, 6, 1-3. [CrossRef]

8. Rennenberg, H.; Brunold, C.; Kok, L.J.D.; Stulen, I. Sulfur Nutrition and Sulfur Assimilation in Higher Plants: Molecular, Biochemical and Physiological Aspects; SPB Academic Publishing: Hague, The Netherlands, 2000; pp. 56-68.

9. Yin, X.H.; Wang, M.; Long, Y.H.; Tian, X.L.; Zhu, L.H.; Li, X.Q.; Xu, C.Y.; Wang, Y. Effects of sulfur treatment on chloroplast ultrastructure and fruit quality. J. Fruit Sci. 2017, 34, 454-463.

10. Wang, M. Prevention and Control Effect of Sulfur on Kiwi Canker Safety; Gui Zhou University: Guiyang, China, 2016. 
11. Bloem, E.; Haneklaus, S.; Schung, E. Milestones in plant sulfur research on sulfur-induced-resistance (SIR) in Europe. Front. Plant Sci. 2015, 5, 779. [CrossRef]

12. Kiraly, L.; Kuenstler, A.; Hoeller, K.; Fattinger, M.; Juhasz, C.; Mueller, M.; Gullner, G.; Zechmann, B. Sulfate supply influences compartment specific glutathione metabolism and confers enhanced resistance to Tobacco mosaic virus during a hypersensitive response. Plant Physiol. Biochem. 2012, 59, 44-54. [CrossRef]

13. Kruse, C.; Jost, R.; Lipschis, M.; Kopp, B.; Hartmann, M.; Hell, R. Sulfur-enhanced defence: Effects of sulfur metabolism, nitrogen supply, and pathogen lifestyle. Plant Biol. 2007, 9, 608-619. [CrossRef]

14. Lima, R.d.C.M.d.; Stamford, N.P.; Santos, C.E.d.R.e.S.; Lira Júnior, M.d.A.; Dias, S.H.L. Eficiência e efeito residual de biofertilizantes de rochas com PK e enxofre com Acidithiobacillus em alface. Hortic. Bras. 2007, 25, 402-407. [CrossRef]

15. Silveira Rabelo, F.H.; de Alcantara da Silva, B.K.; Borgo, L.; Keunen, E.; Rossi, M.L.; Lima Reis Borges, K.; dos Santos, E.F.; dos Reise, A.R.; Martinelli, A.P.; Azevedo, R.A.; et al. Enzymatic antioxidants-Relevant or not to protect the photosynthetic system against cadmium-induced stress in Massai grass supplied with sulfur? Environ. Exp. Bot. 2018, 155, 702-717. [CrossRef]

16. Kopriva, S.; Malagoli, M.; Takahashi, H. Sulfur nutrition: Impacts on plant development, metabolism, and stress responses. J. Exp. Bot. 2019, 70, 4069-4073. [CrossRef]

17. Hussain, S.J.; Masood, A.; Anjum, N.A.; Khan, N.A. Sulfur-mediated control of salinity impact on photosynthesis and growth in mungbean cultivars screened for salt tolerance involves glutathione and proline metabolism, and glucose sensitivity. Acta Physiol. Plant 2019, 41, 1-13. [CrossRef]

18. Fernandes, J.C.; Garcia-Angulo, P.; Goulao, L.F.; Acebes, J.L.; Amancio, S. Mineral stress affects the cell wall composition of grapevine (Vitis vinifera L.). Plant Sci. 2013, 205, 111-120. [CrossRef]

19. Saito, K. Sulfur assimilatory metabolism. The long and smelling road. Plant Physiol. 2004, 136, 2443-2450. [CrossRef]

20. Glazebrook, J. Contrasting mechanisms of defense against biotrophic and necrotrophic pathogens. Annu. Rev. Phytopathol. 2005, 43, 205-227. [CrossRef]

21. Zhang, B.B.; Guo, L.; Song, Z.Z.; Yu, M.L.; Ma, R.J. Effect of salicylic acid on freezing injury in peach floral organs and the expressions of CBF genes. Biol. Plant 2017, 61, 622-630. [CrossRef]

22. Wani, A.B.; Chadar, H.; Wani, A.H.; Singh, S.; Upadhyay, N. Salicylic acid to decrease plant stress. Environ. Chem. Lett. 2017, 15, 101-123. [CrossRef]

23. Moosa, A.; Farzand, A.; Sahi, S.T.; Khan, S.A.; Aslam, M.N.; Zubair, M. Salicylic acid and Cinnamomum verum confer resistance against Penicillium rot by modulating the expression of defense linked genes in Citrus reticulata Blanco. Postharvest Biol. Technol. 2021, 181, 111649. [CrossRef]

24. Lemarie, S.; Robert-Seilaniantz, A.; Lariagon, C.; Lemoine, J.; Marnet, N.; Jubault, M.; Manzanares-Dauleux, M.J.; Gravot, A. Both the Jasmonic Acid and the Salicylic Acid Pathways Contribute to Resistance to the Biotrophic Clubroot Agent Plasmodiophora brassicae in Arabidopsis. Plant Cell Physiol. 2015, 56, 2158-2168. [CrossRef] [PubMed]

25. Liu, L.; Sonbol, F.-M.; Huot, B.; Gu, Y.; Withers, J.; Mwimba, M.; Yao, J.; He, S.Y.; Dong, X. Salicylic acid receptors activate jasmonic acid signalling through a non-canonical pathway to promote effector-triggered immunity. Nat. Commun. 2016, 7, 13099. [CrossRef] [PubMed]

26. Jiao, W.; Li, X.; Wang, X.; Cao, J.; Jiang, W. Chlorogenic acid induces resistance against Penicillium expansum in peach fruit by activating the salicylic acid signaling pathway. Food Chem. 2018, 260, 274-282. [CrossRef]

27. Kasprzewska, A. Plant chitinases-Regulation and function. Cell. Mol. Biol. Lett. 2003, 8, 809-824.

28. Grover, A. Plant Chitinases: Genetic Diversity and Physiological Roles. Crit. Rev. Plant Sci. 2012, 31, 57-73. [CrossRef]

29. Khan, M.F.; Umar, U.U.D. Application of a robust microplate assay to determine induced $\beta-1,3-$ glucanase and chitinase activity in the cotton plant. BioTechniques 2021, 70, 202-208. [CrossRef]

30. Jia, X.; Meng, Q.; Zeng, H.; Wang, W.; Yin, H. Chitosan oligosaccharide induces resistance to Tobacco mosaic virus in Arabidopsis via the salicylic acid-mediated signalling pathway. Sci. Rep. 2016, 6, 26144. [CrossRef]

31. Nechaeva, T.L.; Nikolaeva, T.N.; Zagoskina, N.V. Salicylic and Hydroxybenzoic Acids Affect the Accumulation of Phenolic Compounds in Tea-Plant Cultures in vitro. Biol. Bull. 2020, 47, 374-380. [CrossRef]

32. Cesarino, I. Structural features and regulation of lignin deposited upon biotic and abiotic stresses. Curr. Opin. Biotechnol. 2019, 56, 209-214. [CrossRef]

33. Lee, M.-H.; Jeon, H.S.; Kim, S.H.; Chung, J.H.; Roppolo, D.; Lee, H.-J.; Cho, H.J.; Tobimatsu, Y.; Ralph, J.; Park, O.K. Lignin-based barrier restricts pathogens to the infection site and confers resistance in plants. EMBO J. 2019, 38, 1-17. [CrossRef]

34. Long, Y.; Yin, X.; Wang, M.; Wu, X.; Li, R.; Tian, X.; Li, M. Effects of Sulfur on Kiwifruit Canker Caused by Pseudomonas syringae pv. actinidae. Bangladesh J. Bot. 2017, 46, 1183-1192.

35. Vanneste, J. The Scientific, economic, and social impacts of the New Zealand outbreak of bacterial canker of kiwifruit (Pseudomonas syringae pv. actinidiae). Annu. Rev. Phytopathol. 2017, 55, 377-399. [CrossRef]

36. Froud, K.J.; Beresford, R.M.; Cogger, N.C. Impact of kiwifruit bacterial canker on productivity of cv. Hayward kiwifruit using observational data and multivariable analysis. Plant Pathol. 2018, 67, 671-681. [CrossRef]

37. Beatrice, C.; Linthorst, J.M.; Cinzia, F.; Luca, R. Enhancement of PR1 and PR5 gene expressions by chitosan treatment in kiwifruit plants inoculated with Pseudomonas syringae pv. actinidiae. Eur. J. Plant Pathol. 2017, 148, 163-179. [CrossRef]

38. Garcia-Mina, J.M. Plant nutrition and defense mechanism: Frontier knowledge. In Advances in Citrus Nutrition; Universidad de Navarra: Navarra, Spain, 2012; pp. 1-12. 
39. Zhang, Y.; Suzuki, K.; Liu, H.; Nukaya, A.; Kiriiwa, Y. Fruit yellow-shoulder disorder as related to mineral element uptake of tomatoes grown in high temperature. Sci. Hortic. 2018, 242, 25-29. [CrossRef]

40. Romera, F.J.; Garcia, M.J.; Lucena, C.; Martinez-Medina, A.; Aparicio, M.A.; Ramos, J.; Alcantara, E.; Angulo, M.; Perez-Vicente, R. Induced Systemic Resistance (ISR) and Fe Deficiency Responses in Dicot Plants. Front. Plant Sci. 2019, 10, 17. [CrossRef]

41. McKenna, P.; Cannon, N.; Conway, J. Soil mineral nitrogen availability predicted by herbage yield and disease resistance in red clover (Trifolium pratense) cropping. Nutr. Cycl. Agroecosyst. 2018, 112, 303-315. [CrossRef]

42. Lopez-Zaplana, A.; Barzana, G.; Agudelo, A.; Carvajal, M. Foliar Mineral Treatments for The Reduction of Melon (Cucumis melo L.) Fruit Cracking. Agronomy 2020, 10, 1815. [CrossRef]

43. Anjum, N.A.; Gill, R.; Kaushik, M.; Hasanuzzaman, M.; Pereira, E.; Ahmad, I.; Tuteja, N.; Gill, S.S. ATP-sulfurylase, sulfurcompounds, and plant stress tolerance. Front. Plant Sci. 2015, 6, 1-9. [CrossRef]

44. Alvarez, C.; Angeles Bermudez, M.; Romero, L.C.; Gotor, C.; Garcia, I. Cysteine homeostasis plays an essential role in plant immunity. New Phytol. 2012, 193, 165-177. [CrossRef]

45. Datta, R.; Chattopadhyay, S. Glutathione as a crucial modulator of phytohormonesignalling during pathogen defence in plants. Proc. Indian Natl. Sci. Acad. 2018, 84, 581-597. [CrossRef]

46. Gullner, G.; Juhasz, C.; Nemeth, A.; Barna, B. Reactions of tobacco genotypes with different antioxidant capacities to powdery mildew and Tobacco mosaic virus infections. Plant Physiol. Biochem. 2017, 119, 232-239. [CrossRef]

47. Hoeller, K.; Kiraly, L.; Kuenstler, A.; Mueller, M.; Gullner, G.; Fattinger, M.; Zechmann, B. Enhanced Glutathione Metabolism Is Correlated with Sulfur-Induced Resistance in Tobacco mosaic virus-Infected Genetically Susceptible Nicotiana tabacum Plants. Mol. Plant-Microbe Interact. 2010, 23, 1448-1459. [CrossRef]

48. Moniuszko, G.; Skoneczny, M.; Zientara-Rytter, K.; Wawrzynska, A.; Glow, D.; Cristescu, S.M.; Harren, F.J.M.; Sirko, A. Tobacco LSU-like protein couples sulphur-deficiency response with ethylene signalling pathway. J. Exp. Bot. 2013, 64, 5173-5182. [CrossRef]

49. Rajab, H.; Khan, M.S.; Malagoli, M.; Hell, R.; Wirtz, M. Sulfate-Induced Stomata Closure Requires the Canonical ABA Signal Transduction Machinery. Plants 2019, 8, 21. [CrossRef]

50. Kruse, C.; Haas, F.H.; Jost, R.; Reiser, B.; Reichelt, M.; Wirtz, M.; Gershenzon, J.; Schnug, E.; Hell, R. Improved sulfur nutrition provides the basis for enhanced production of sulfur-containing defense compounds in Arabidopsis thaliana upon inoculation with Alternaria brassicicola. J. Plant Physiol. 2012, 169, 740-743. [CrossRef]

51. Han, Y.; Chaouch, S.; Mhamdi, A.; Queval, G.; Zechmann, B.; Noctor, G. Functional Analysis of Arabidopsis Mutants Points to Novel Roles for Glutathione in Coupling $\mathrm{H}_{2} \mathrm{O}_{2}$ to Activation of Salicylic Acid Accumulation and Signaling. Antioxid. Redox Signal. 2013, 18, 2106-2121. [CrossRef]

52. Appa, B.; Hfa, C.; Et, A. Nitrogen, phosphorous and potassium levels affected growth indices, leaf gas exchange parameters and biomass production of henna (Lawsonia inermis L.) ecotypes. Ind. Crop. Prod. 2021, 163, 113297. [CrossRef]

53. Broekaert, W.F.; Terras, F.; Cammue, B. Induced and Preformed Antimicrobial Proteins. In Mechanisms of Resistance to Plant Diseases; RWTH: Aachen, Germany, 2000; pp. 371-477.

54. Pettongkhao, S.; Bilanglod, A.; Khompatara, K.; Churngchow, N. Sulphated Polysaccharide from Acanthophora spicifera Induced Hevea brasiliensis Defense Responses Against Phytophthora palmivora Infection. Plants 2019, 8, 73. [CrossRef]

55. Yang, T.; Wang, Y. Research progress of plant pathogenesis related protein PR-10. Zhiwu Shengli Xuebao/Plant Physiol. J. 2017, 53, 2057-2068.

56. Li, X.; Zhu, L.; Tu, L.; Liu, L.; Yuan, D.; Li, J.; Lu, L.; Zhang, X. Lignin metabolism has a central role in the resistance of cotton to the wilt fungus Verticillium dahliae as revealed by RNA-Seq-dependent transcriptional analysis and histochemistry. J. Exp. Bot. 2011, 62, 5607-5621. [CrossRef]

57. Onohata, T.; Gomi, K. Overexpression of jasmonate-responsive OsbHLH034 in rice results in the induction of bacterial blight resistance via an increase in lignin biosynthesis. Plant Cell Rep. 2020, 39, 1175-1184. [CrossRef] [PubMed]

58. Cao, S.; Huang, C.; Luo, L.; Zheng, S.; Zhong, Y.; Sun, J.; Gui, J.; Li, L. Cell-Specific Suppression of 4-Coumarate-CoA Ligase Gene Reveals Differential Effect of Lignin on Cell Physiological Function in Populus. Front. Plant Sci. 2020, 17. [CrossRef]

59. Tang, Y.; Liu, F.; Xing, H.; Mao, K.; Chen, J. Correlation Analysis of Lignin Accumulation and Expression of Key Genes Involved in Lignin Biosynthesis of Ramie (Boehmeria nivea). Genes 2019, 10, 389. [CrossRef]

60. Chatelet, D.S.; Wistrom, C.M.; Purcell, A.H.; Rost, T.L.; Matthews, M.A. Xylem structure of four grape varieties and 12 alternative hosts to the xylem-limited bacterium Xylella fastidious. Ann. Bot. 2011, 108, 73-85. [CrossRef]

61. Lu, G.; Li, Z.; Zhang, X.; Wang, R.; Yang, S. Expression Analysis of Lignin-Associated Genes in Hard End Pear (Pyrus pyrifolia Whangkeumbae) and Its Response to Calcium Chloride Treatment Conditions. J. Plant Growth Regul. 2015, 34, 251-262. [CrossRef]

62. Schurt, D.A.; Rodrigues, F.A.; Colodette, J.L.; Carre-Missio, V. Effect of silicon on lignin and sugar concentrations of leaf sheaths in rice plants infected by Rhizoctonia solani. Bragantia 2013, 72, 360-366. [CrossRef]

63. Carvalho, E.R.; Oliveira, J.A.; Reis, L.V.; Ferreira, E.T.F. Mn foliar sobre a qualidade sanitária e lignina de sementes de soja convencional e resistente ao glifosato1. Rev. Ciênc. Agronmica 2014, 46, 135-143. [CrossRef]

64. Gorshkov, V.Y.; Daminova, A.G.; Mikshina, P.V.; Petrova, O.E.; Ageeva, M.V.; Salnikov, V.V.; Gorshkova, T.A.; Gogolev, Y.V. Pathogen-induced conditioning of the primary xylem vessels-A prerequisite for the formation of bacterial emboli by Pectobacterium atrosepticum. Plant Biol. 2016, 18, 609-617. [CrossRef] 
65. Zhang, D.; Hrmova, M.; Wan, C.-H.; Wu, C.; Balzen, J.; Cai, W.; Wang, J.; Densmore, L.D.; Fincher, G.B.; Zhang, H.; et al. Members of a new group of chitinase-like genes are expressed preferentially in cotton cells with secondary walls. Plant Mol. Biol. 2004, 54, 353-372. [CrossRef]

66. Gupta, P.; Ravi, I.; Sharma, V. Induction of $\beta$-1,3-glucanase and chitinase activity in the defense response of Eruca sativa plants against the fungal pathogen Alternaria brassicicola. J. Plant Interact. 2013, 8, 155-161. [CrossRef]

67. Yoshida, K.; Ogino, A.; Yamada, K.; Sonod, R. Induction of Disease Resistance in Tea (Camellia sinensis L.) by Plant Activators. Japan Agricultural Research Quarterly 2010, 44, 391-398. [CrossRef]

68. Page, A.L.; Miller, R.H.; Keeney, D.R. Chemical and Microbiological Properties; American Society of Agronomy: Washington, DC, USA, 1982; pp. 86-110.

69. Lichtenthaler, H.K.; Wellburn, A.R. Determinations of total carotenoids and chlorophylls a and b of leaf extracts in different solvents. Analysis 1983, 11, 591-592. [CrossRef]

70. De Sá, M.; Ferreira, J.P.; Queiroz, V.T.; Vilas-Boas, L.; Silva, M.C.; Almeida, M.H.; Guerra-Guimarães, L.; Bronze, M.R. A liquid chromatography/electrospray ionisation tandem mass spectrometry method for the simultaneous quantification of salicylic, jasmonic and abscisic acids in Coffea arabica leaves. J. Sci. Food Agric. 2014, 94, 529-536. [CrossRef]

71. Liang, M.; Davis, E.; Gardner, D.; Cai, X.; Wu, Y. Involvement of AtLAC15 in lignin synthesis in seeds and in root elongation of Arabidopsis. Planta 2006, 224, 1185-1196. [CrossRef]

72. Pomar, F.; Novo, M.; Bernal, M.A.; Merino, F.; Barchelo, A.R. Changes in stem lignins (monomer composition and crosslinking) and peroxidase are related with the maintenance of leaf photosynthetic integrity during Verticillium wilt in Capsicum annuum. New Phytol. 2004, 163, 111-123. [CrossRef]

73. Boller, T.; Gehri, A.; Mauch, F.; Vogeli, U. Chitinase in bean leaves: Induction by ethylene, purification, properties, and possible function. Planta 1983, 157, 22-31. [CrossRef]

74. Pan, S.Q.; Ye, X.S.; Kuć, J. Association of $\beta-1,3-$ glucanase activity and isoform pattern with systemic resistance to blue mould in tobacco induced by stem injection with Peronospora tabacina or leaf inoculation with tobacco mosaic virus. Physiol. Mol. Plant Pathol. 1991, 39, 25-39. [CrossRef] 